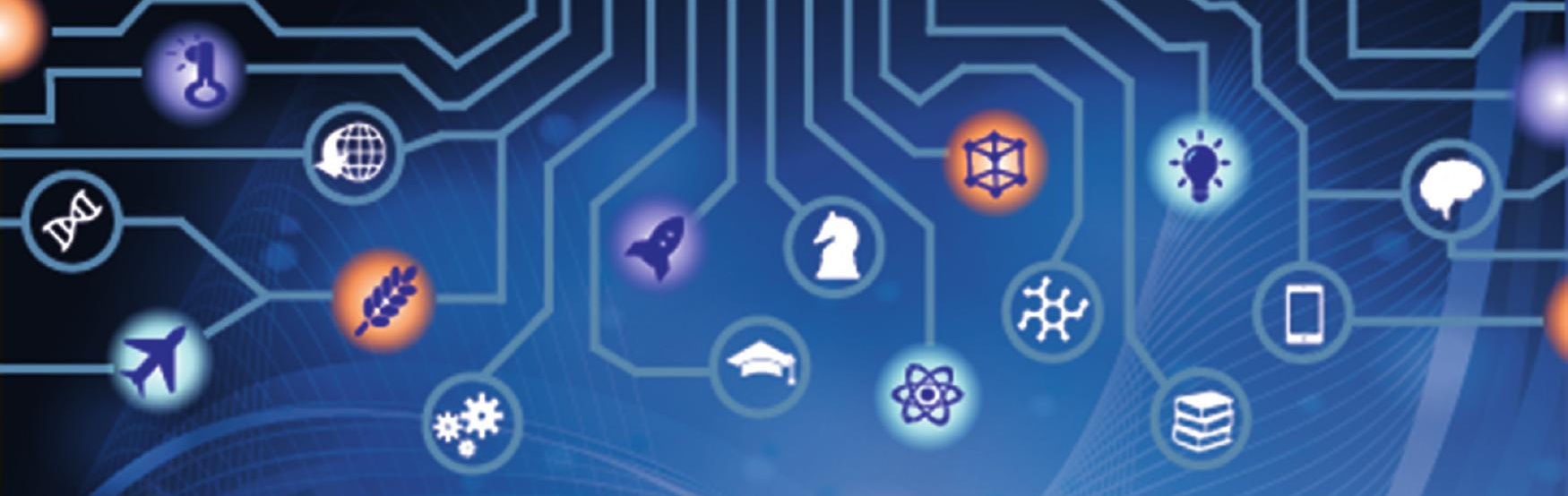

\title{
ANALYSIS OF INTRA GCC MERCHANDISE TRADE DURING 1995-2015 AMIDST GCC DIVERSIFICATION INITIATIVES
}

\author{
Subhadra Ganguli \\ Associate Professor, Ahlia University Manama, \\ Kingdom of Bahrain \\ E-mail: subhadra.ganguli@gmail.com
}

\begin{abstract}
Purpose: One of the aims of a single currency zone is a thriving and robust intra-regional trade. Previous literature concluded that Bahrain exhibited high dissimilarity of exports within the Gulf Cooperation Council (GCC) compared to exports of other GCC states within the region (Ganguli, 2018, forthcoming) during 1995-2015. This paper aims to evaluate the potential of a single currency GCC union by analysing the detailed export structure of goods between Bahrain and the rest of the GCC to check for export diversity.

Design/methodology/approach: A quantitative analysis was applied to time-series merchandise data of export items with a three-digit Standard Industrial Classification (SIC) code. These were extracted from the United Nations Conference on Trade and Development (UNCTADstat) database for the period 1995-2015.

Findings: Bahrain's merchandise exports within the GCC displayed significant diversity in terms of composition during 1995 to 2015. Merchandise export diversity has similarities with the diversification trends of the economy.

Originality/value: Evidence of export diversification from Bahrain to other GCC states shows that Bahrain can be used as a model for other GCC states for diversification of exports to create a sustainable GCC currency union.

Keywords: sustainability; GCC; SIC; exports; manufactured goods

Reference to this paper should be made as follows: S. Ganguli, (2017) 'Analysis of Intra GCC Merchandise Trade during 1995-2015 amidst GCC Diversification Initiatives', Int. J. of Innovation and Knowledge Management in the Middle East and North Africa, Vol.6, No.1, pp. 41-60.
\end{abstract}




\section{INTRODUCTION}

The formation of the Gulf Cooperation Council (GCC) in 1981 between Bahrain, Kuwait, Qatar, Oman, United Arab Emirates (UAE) and Saudi Arabia was aimed at creating a single currency monetary union by 2010. Although it remains an unfulfilled dream, GCC members have strengthened economic ties through the formation of a common market and a customs union. Ganguli (2016) argues that the convergence factors for a successful currency union were not met, especially during the period of continued low oil prices during 2004-15, due to heavy dependence of the GCC region on oil and oil related goods and services, and lack of diversification. Ganguli (2018) concludes that while the Bahrain merchandise export structure shows dissimilarity when compared with exports of other GCC states during 1995-2015, its imports appear to be very similar to those of its GCC trade partners. The other five GCC states show more similarity among themselves in both merchandise exports and imports than those of Bahrain. Only the UAE has shown an increase in both concentration and diversification indices during 1995-2015 in its export basket within GCC, although the increased numbers are still lower than those of the other GCC states and low in absolute terms.

This paper analyses merchandise export data from Bahrain to the rest of the GCC during 19952015, to identify the nature of diverse exports to the rest of the GCC for sustainable intra-GCC trade, should such diversity exist. The paper explores similarities between diversification of the economy and diversification of exports to GCC during 1995-2015.

\section{KINGDOM OF BAHRAIN: DIVERSIFICATION EFFORTS IN THE ECONOMY}

The IMF Executive Board concluded the Article IV Consultation with the Kingdom of Bahrain (2017), mentioning that:

“Overall GDP grew 3 percent in 2016, supported by strong growth of 3.7 percent in the non-oil sector aided by the implementation of GCC-funded projects. Real GDP growth is expected to slow to 2.3 and 1.6 percent in 2017 and 2018, reflecting the ongoing fiscal consolidation and weaker investor sentiment."

According to the IMF, the non-oil sector accounts for $76 \%$ of Bahrain's total GDP. The non-oil sector showed a healthy 4.4\% growth in the first quarter of 2017, up from 3.7\% during 2016 (Bahrain Economic Quarterly, 2017). The five pillars of diversification in the Kingdom of Bahrain are the financial services, industrial and manufacturing, logistics, tourism and Information Communications Technology (ICT).

Bahrain's financial sector is well developed and diversified; this is evident by the remarkable presence of a wide range of local, regional, conventional and Islamic financial institutions, with a combination of retail and wholesale banks, insurance companies, brokers and advisors as well as security brokers and mutual funds. The sector is one of the largest employers, with a total of $66 \%$ of the work force comprising of Bahraini nationals. Overall, the financial sector is accountable for 16.7\% of Bahrain's Gross Domestic Product (GDP) (Ganguli and Matar, 2016).

State aluminium producer Aluminium Bahrain's (Alba) \$3bn Line 6 Expansion project is predicted to give Bahrain the status of the largest aluminium smelter in the world; additionally a $\$ 1$ bn airport modernisation contract, and a \$355m Banagas gas plant projects are on the way. 
Bahrain's location at the heart of the GCC, and as a link between the east and the west, helps in transport operations to provide the natural logistics of transport to support its manufacturing and tourism sectors. According to Bloomberg (2017), Bahrain has been ranked first among the top 10 destinations for expatriates to live, raise a family and for being made welcome as a foreigner.

The Central Bank of Bahrain (CBB) has launched regulations and licensing for implementing Fintech technology, welcoming innovations in the financial sector. CBB's governor, Rasheed Mohammed Al Maraj (2017), forecasted 2017's non-oil GDP growth to be 3.5\%. Bahrain 2030's economic vision aimed to provide a robust and vibrant private sector with the employment of Bahrainis who will be able to access proper healthcare, education and a sound and secure environment. Its national development strategy aimed to develop a sound business environment, doubling the income of Bahrainis through a competitive economy boosted by a growing private sector. Bahrain aims to build a knowledge-based economy (Ganguli, 2018).

Currently, the main industries in Bahrain are petroleum processing and refining, aluminium smelting, iron pelletisation, fertilisers, Islamic and offshore banking, insurance, ship repairing and tourism. Agriculture's current share of GDP is $0.3 \%$, with $47.1 \%$ in manufacturing and $52.2 \%$ in services (IMF, 2016). Oil revenue comprised of $86.2 \%$ of the total fiscal revenue of the kingdom, and oil and gas exports comprised of $60.9 \%$ of the share of total exports from the kingdom (IMF, 2016).

\section{LITERATURE REVIEW}

Ganguli (2016) shows that in the face of low oil prices, GCC economies do not exhibit the convergence of their macroeconomic indicators necessary for the formation of single currency monetary union, especially in the wake of low oil prices and lack of adequate diversification. Nechi (2010) shows that intra-GCC trade and financial integration remain weak, except for Bahrain and Kuwait who invest a large amount of their capital within the GCC. However, the GCC remains largely dependent on oil, with weak trade links within themselves. Ravi (2013) shows some degree of intra-industry trade within the GCC, with mineral fuel trade and intra-GCC trade being dominated by Saudi Arabia.

Boughanmi (2008) expects the customs union in the GCC to unleash new potential for trade within the GCC, which seems to have reached its full trade potential. Although GCC states exhibit low trade among them, it does not seem to be insignificant compared to the prediction of the gravity trade model applied to the study. Sahib and Kari (2012) conclude that Bahrain, Kuwait, Oman and Qatar did not obtain a comparative advantage in their non-oil sector in exports compared to Saudi Arabia and UAE during 1998-2008.

A lack of diversification and intra-GCC trade has led the GCC economies to integrate more with non-GCC countries than within themselves. Hossain and Naser (2008) show, among other results, that intra-GCC exports and imports and high-tech manufacturing exports show rising trends after the implementation of the GCC customs union. Alawadhi (2014) mentioned that intra-GCC trade is neither deep nor effective in large intra-trade industry trade or in the trade of new products. The level of integration is not enough to create the basis for a common currency union. Al Said (2007) concludes that there is intra-industry trade due to significant mineral fuel trade in the GCC. Although small in size, Oman and Bahrain trade significant amounts within the GCC. 
Ganguli (2018) concludes that while the Bahrain merchandise export structure within the GCC shows dissimilarity from those of other GCC states during 1995-2015, its imports appear to be very similar with those of the rest. The other five GCC states show more similarity among themselves in both merchandise exports and imports than that of Bahrain. Only the UAE has shown an increase in both concentration and diversification indices of exports, although the increased numbers are still lower than those of the other GCC states and low in absolute terms.

\section{DATA AND METHODOLOGY}

The paper extracted data on merchandise exports of Bahrain to each of the GCC states, namely Saudi Arabia, Kuwait, Qatar, Oman and the UAE, from the UNCTADstat (United Nations Conference on Trade and Development) database; this is available publicly on the website http:// unctad.org/en/Pages/statistics.aspx. The data analysed in the paper have been extracted from the UNCTAD database for the years 1995-2015. The data table named Merchandise trade matrix - detailed products, exports in thousands of dollars, annual, 1995-2016 ${ }^{1}$ provides merchandise trade by trading partner (namely GCC states individually) and products based on 3-digit level Standard International Trade Classification (SITC) Revision 3 commodity classification, expressed in thousands of dollars during 1995-2015. The sources of the data collected by UNCTAD are UNCTAD secretariat calculations, based on UN DESA Statistics Division, UN COMTRADE; IMF, Direction of Trade Statistics; UNCTAD, UNCTADstat Merchandise Trade Indices and Total Merchandise Trade. The SITC Revision 3 commodity classification can be found in Table 1.

Each of the categories (0-9) in Table 1 can be further split into 2-digit sub-categories, and each of the 2-digit categories can then be split into 3-digit sub-categories: an example is presented in the Appendix. E.g., the category 0 (which is Food and Live Animals) is further broken down into 00-09 categories (please see Appendix), each of which is further divided into 3-digit levels namely, 00 (which is live animals other than animals of division 03) is split into 001. It is at this 001 3-digit code that UNCTADstat reports the detailed product exports table. The 3-digit data has been aggregated into 3-digit and then finally into single digit data for the purposes of analysis in the paper, as per SITC Rev 3 classification. Hence the paper analyses data at the single digit following the SITC Rev 3 classification as in Table 1.

Bahrain's merchandise exports for the period 1995-2015 collected from the UNCTADstat database has been classified into the categories $0-9$ in Table 1 . Tables $2-6$ provide the aggregated data organised for the 0-9 categories of export items from Bahrain to the individual GCC states, namely Saudi Arabia (Table 2), Kuwait (Table 3),

Oman (Table 4), Qatar (Table 5), UAE (Table 6) for the period 1995-2015. Tables 2-6 also provide rankings of the export categories in terms of first, second and third based on their share in total product exports to each of these countries. Rank 1 is given to the product that has the highest share in total exports, followed by rank 2 by theproduct that comes next in terms of percentage of its exports in total exports, and finally rank 3 is for the product that has the third largest share of exports in total exports of Bahrain to the GCC.

${ }^{1}$ The paper uses data up to 2015 only. 
Table 1 Standard International Trade Classification, Rev.3

\begin{tabular}{cl}
\hline SITC Code & \multicolumn{1}{c}{ Product Classification } \\
\hline 0 & Food and live animals \\
1 & Beverages and tobacco \\
2 & Crude materials, inedible, except fuels \\
3 & Mineral fuels, lubricants and related materials \\
4 & Animal and vegetable oils, fats and waxes \\
5 & Chemicals and related products, n.e.s. \\
6 & Manufactured goods classified chiefly by material \\
7 & Machinery and transport equipment \\
8 & Miscellaneous manufactured articles \\
9 & Commodities and transactions not classified elsewhere in the SITC \\
I & Gold, monetary \\
II & Gold coin and current coin \\
\hline
\end{tabular}

Source: https://unstats.un.org/unsd/cr/registry/regcst.asp?Cl=14

Table 2 Bahrain Exports to Saudi Arabia by Composition, 1995 vs. 2015

\begin{tabular}{|c|c|c|c|c|}
\hline Product Category (incl. SITC code) & $\begin{array}{c}1995 \\
\text { (\% of Total) }\end{array}$ & rank & $\begin{array}{c}2015 \\
\text { (\% of Total) }\end{array}$ & Rank \\
\hline [0] Food and live animals & $3 \%$ & & $8 \%$ & \\
\hline [1] Beverages and tobacco & $0 \%$ & & $1 \%$ & \\
\hline [2] Crude materials, inedible, except fuels & $6 \%$ & & $0 \%$ & \\
\hline [3] Mineral fuels, lubricants and related materials & $0 \%$ & & $6 \%$ & \\
\hline [4] Animal and vegetable oils, fats and waxes & $6 \%$ & & $0 \%$ & \\
\hline [5] Chemicals and related products, n.e.s. & $3 \%$ & & $7 \%$ & \\
\hline [6] Manufactured goods & $71 \%$ & 1 & $44 \%$ & 1 \\
\hline [7] Machinery and transport equipment & $5 \%$ & & $18 \%$ & 2 \\
\hline [8] Miscellaneous manufactured articles & $6 \%$ & & $12 \%$ & 3 \\
\hline [9] Commodities and transactions, n.e.s. & $0 \%$ & & $3 \%$ & \\
\hline
\end{tabular}

Source: Merchandise Trade Matrix: detailed products, exports in thousands of dollars, annual, 1995-2016, UNCTAD

\section{Findings}

Bahrain's exports to Saudi Arabia show that while manufactured goods ranked $1^{\text {st }}$ with $71 \%$ of the exports in 1995, it continued to have the major share in 2015, maintaining first rank. However, its share in total exports to Saudi Arabia declined from 71\% in 1995 to $44 \%$ in 2015. Machinery and miscellaneous manufactured articles ranked

In 1995, two major categories of exports to Qatar comprised of manufactured articles, which consisted of $33 \%$ of total exports, ranking first, and crude materials, inedible, except fuels, which consisted of 31\% of total exports with a rank of second. In 2015 manufactured articles comprised of $15 \%$ ranking third, and crude materialssecond and third in 2015 respectively, as their shares in 
total exports increased to $18 \%$ and $12 \%$ respectively from very insignificant percentages in 1995 (refer to Table 2 and Figure 1).

Bahrain's exports to Kuwait show that in 1995, manufactured goods and miscellaneous manufactured articles ranked first and second with $65 \%$ and $22 \%$ of total exports respectively. In 2015, manufactured goods still maintained first rank, although with only $25 \%$ of the total exports, with a new product group, namely food and live animals, taking up the top rank. This was followed by machinery and transport equipment at 20\%, and miscellaneous manufactured articles as the third category at $16 \%$ (refer to Table 3 and Figure 2 ).

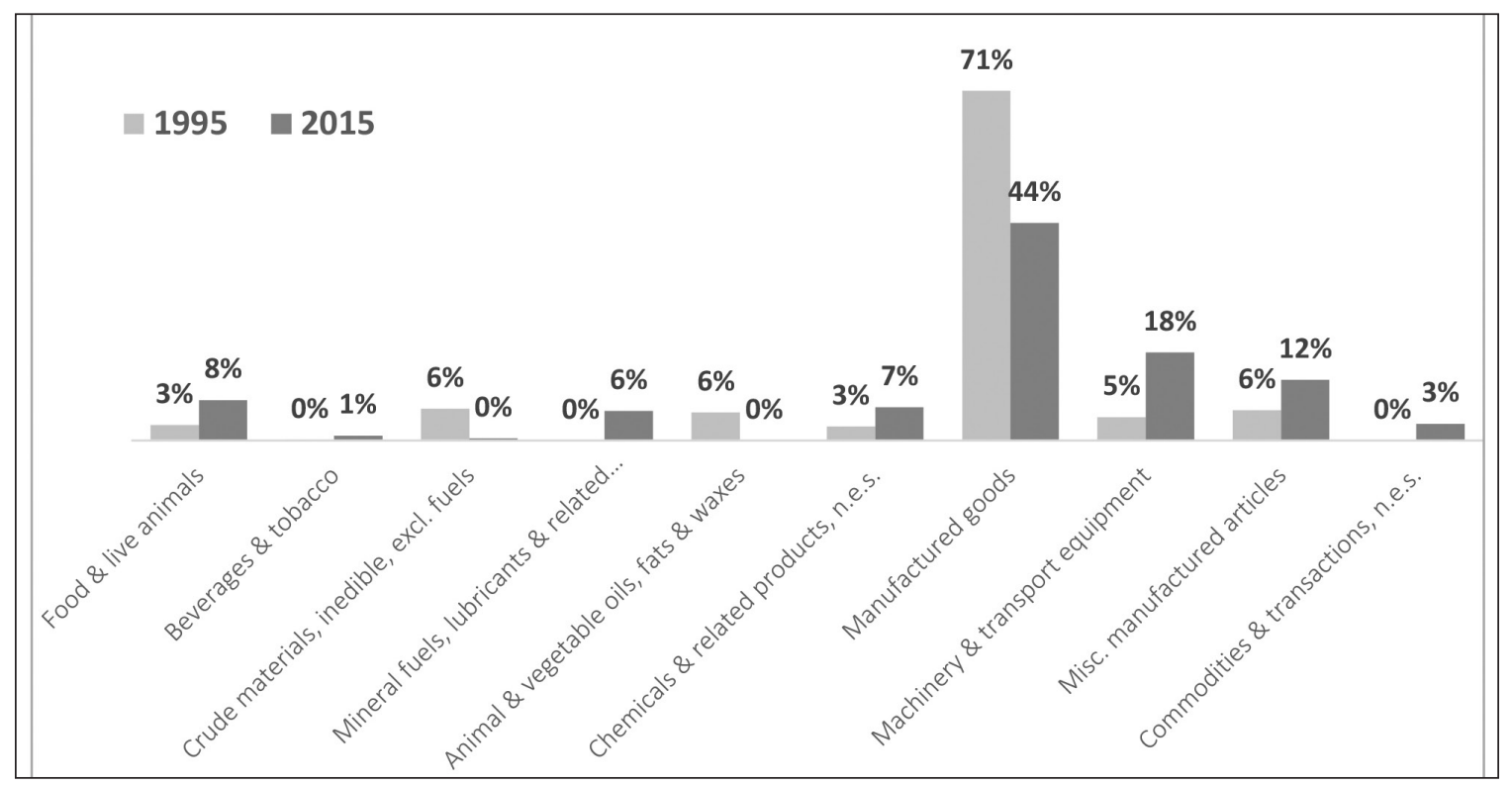

Figure 1 Primary Export Categories to Saudi Arabia, 1995 vs. 2015

Source: Merchandise Trade Matrix: detailed products, exports in thousands of dollars, annual, 1995-2016, UNCTAD

Table 3 Bahrain Exports to Kuwait by Composition, 1995 vs. 2015

\begin{tabular}{|c|c|c|c|c|}
\hline Product Category (incl. SITC code) & $\begin{array}{c}1995 \\
\text { (\% of Total) }\end{array}$ & rank & $\begin{array}{c}2015 \\
\text { (\% of Total) }\end{array}$ & Rank \\
\hline [0] Food and live animals & $9 \%$ & & $25 \%$ & 1.00 \\
\hline [1] Beverages and tobacco & $1 \%$ & & $1 \%$ & \\
\hline [2] Crude materials, inedible, except fuels & $0 \%$ & & $0 \%$ & \\
\hline [3] Mineral fuels, lubricants and related materials & $0 \%$ & & $0 \%$ & \\
\hline [4] Animal and vegetable oils, fats and waxes & $4 \%$ & & $0 \%$ & \\
\hline [5] Chemicals and related products, n.e.s. & $4 \%$ & & $14 \%$ & 3 \\
\hline [6] Manufactured goods & $56 \%$ & 1 & $25 \%$ & 1 \\
\hline [7] Machinery and transport equipment & $5 \%$ & & $20 \%$ & \\
\hline [8] Miscellaneous manufactured articles & $22 \%$ & 2 & $16 \%$ & 2 \\
\hline [9] Commodities and transactions, n.e.s. & $0 \%$ & & $0 \%$ & \\
\hline
\end{tabular}

Source: Merchandise Trade Matrix: detailed products, exports in thousands of dollars, annual, 1995-2016, UNCTAD 


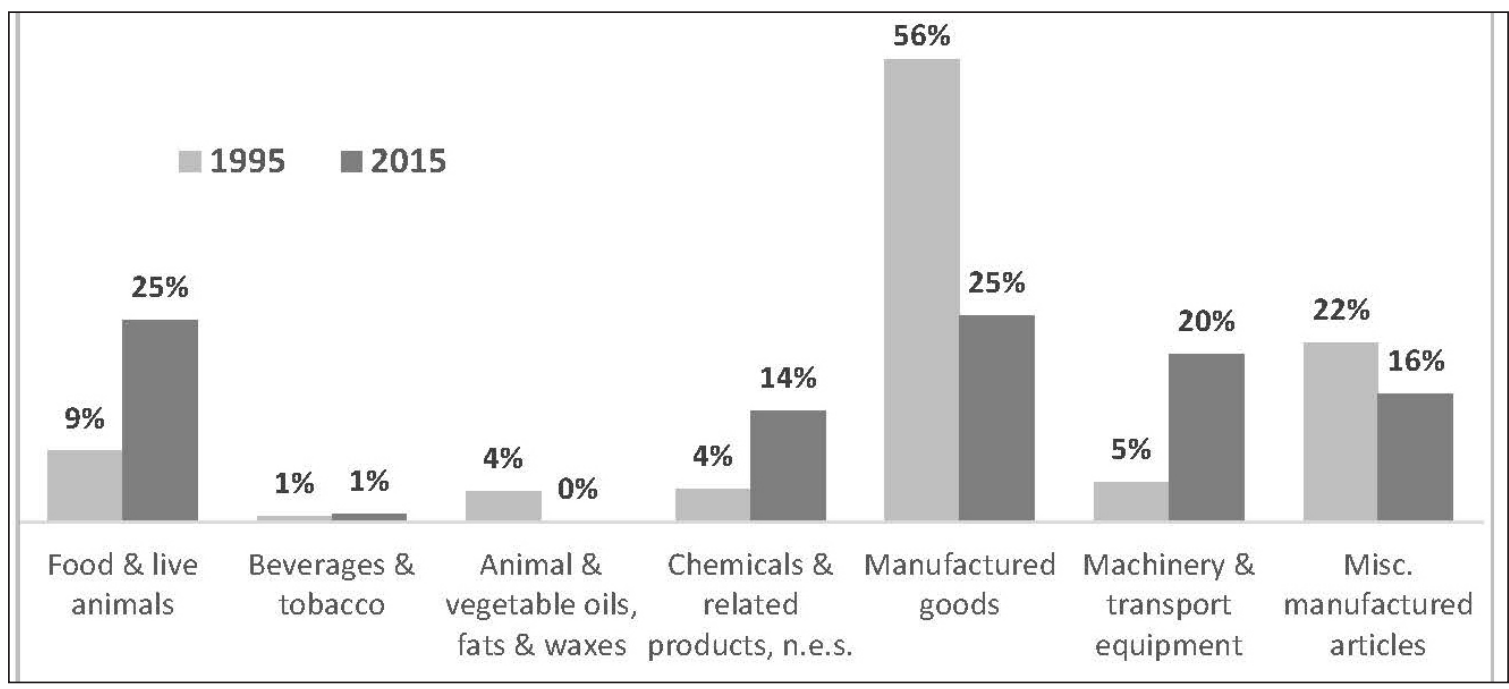

Figure 2 Primary Export Categories to Kuwait, 1995 vs. 2015

Source: Merchandise Trade Matrix: detailed products, exports in thousands of dollars, annual, 1995-2016, UNCTAD

Table 4 Bahrain Exports to Oman by Composition, 1995 vs. 2015

\begin{tabular}{|c|c|c|c|c|}
\hline Product Category (incl. SITC code) & $\begin{array}{c}1995 \\
\text { (\% of Total) }\end{array}$ & rank & $\begin{array}{c}2015 \\
\text { (\% of Total) }\end{array}$ & rank \\
\hline [0] Food and live animals & $5 \%$ & & $1 \%$ & \\
\hline [1] Beverages and tobacco & $2 \%$ & & $4 \%$ & \\
\hline [2] Crude materials, inedible, except fuels & $6 \%$ & & $9 \%$ & \\
\hline [3] Mineral fuels, lubricants and related materials & $1 \%$ & & $44 \%$ & 1 \\
\hline [4] Animal and vegetable oils, fats and waxes & $18 \%$ & & $0 \%$ & \\
\hline [5] Chemicals and related products, n.e.s. & $4 \%$ & & $7 \%$ & \\
\hline [6] Manufactured goods & $18 \%$ & 2 & $17 \%$ & 2 \\
\hline [7] Machinery and transport equipment & $27 \%$ & 1 & $6 \%$ & \\
\hline [8] Miscellaneous manufactured articles & $17 \%$ & 3 & $12 \%$ & 3 \\
\hline [9] Commodities and transactions, n.e.s. & $2 \%$ & & $0 \%$ & \\
\hline
\end{tabular}

Source: Merchandise Trade Matrix: detailed products, exports in thousands of dollars, annual, 1995-2016, UNCTAD

Exports to Oman show no major shift in export product categories between 1995 and 2015, however, there appears to be a shift in the percentages of exports among the major export products. These are mineral fuels, lubricants and related materials, manufactured goods, machinery and transport equipment and miscellaneous and manufactured articles. Animals, vegetable oils, fats and waxes, which consisted of 18\% of total exports in 1995, do not show any share in 2015. Further analysis needs to be carried out regarding the trend of this category of exports to make a more detailed conclusion (refer to Table 4 and Figure 3).

In 1995, two major categories of exports to Qatar comprised of manufactured articles, which consisted of $33 \%$ of total exports, ranking first, and crude materials, inedible, except fuels, which consisted of 31\% of total exports with a rank of second. In 2015 manufactured articles comprised 


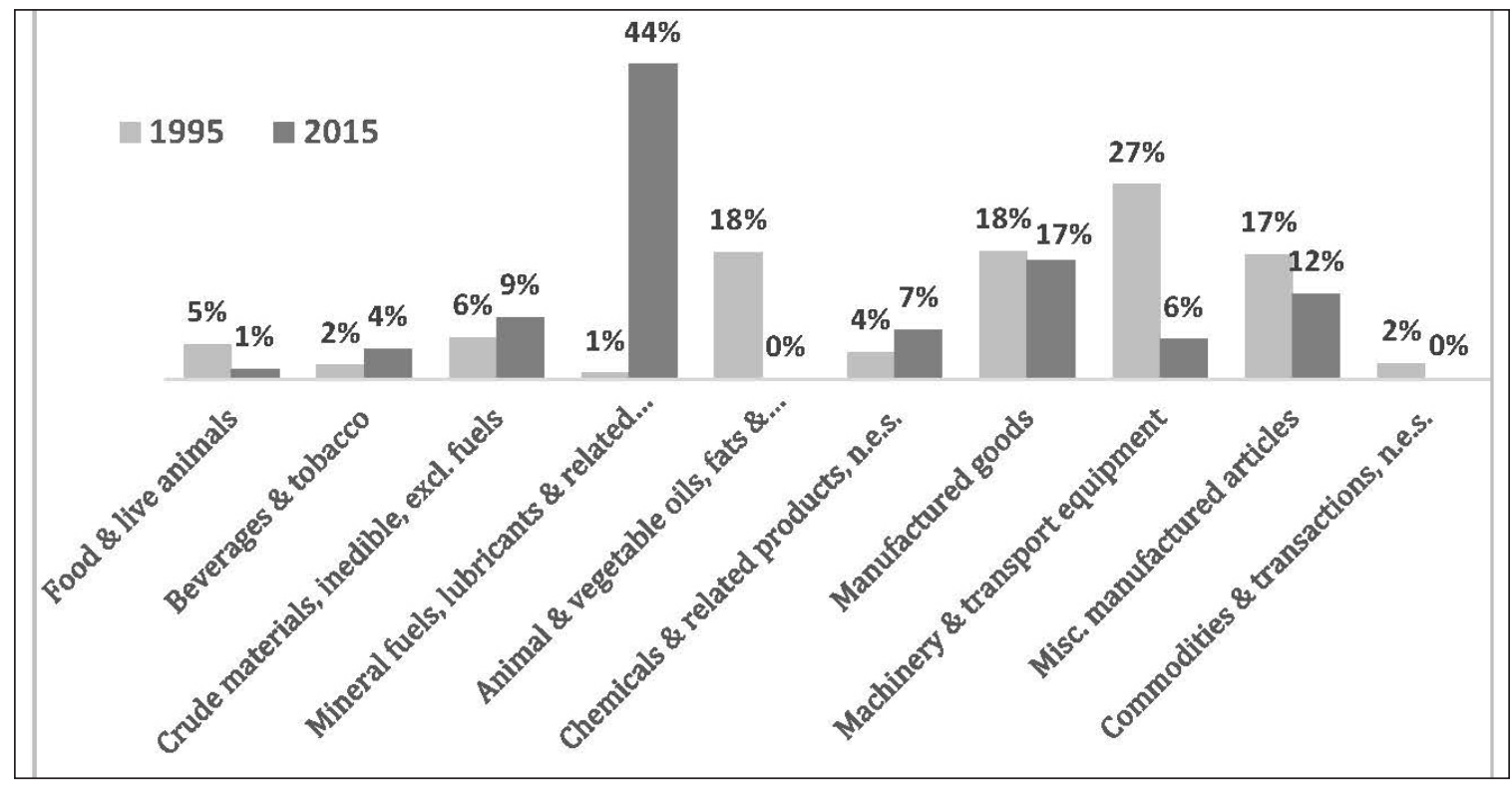

Figure 3 Primary Export Categories to Oman, 1995 vs. 2015

Source: Merchandise Trade Matrix: detailed products, exports in thousands of dollars, annual, 1995-2016, UNCTAD

Table 5 Bahrain Exports to Qatar by Composition, 1995 vs. 2015

\begin{tabular}{|c|c|c|c|c|}
\hline Product Category (incl. SITC code) & $\begin{array}{c}1995 \\
\text { (\% of Total) }\end{array}$ & rank & $\begin{array}{c}2015 \\
\text { (\% of Total) }\end{array}$ & rank \\
\hline [0] Food and live animals & $3 \%$ & & $8 \%$ & \\
\hline [1] Beverages and tobacco & $0 \%$ & & $7 \%$ & \\
\hline [2] Crude materials, inedible, except fuels & $31 \%$ & 2 & $17 \%$ & 2 \\
\hline [3] Mineral fuels, lubricants and related materials & $2 \%$ & & $29 \%$ & 1 \\
\hline [4] Animal and vegetable oils, fats and waxes & $9 \%$ & & $0 \%$ & \\
\hline [5] Chemicals and related products, n.e.s. & $3 \%$ & & $11 \%$ & \\
\hline [6] Manufactured goods & $33 \%$ & 1 & $15 \%$ & 3 \\
\hline [7] Machinery and transport equipment & $4 \%$ & & $7 \%$ & \\
\hline [8] Miscellaneous manufactured articles & $8 \%$ & & $4 \%$ & \\
\hline [9] Commodities and transactions, n.e.s. & $6 \%$ & & $0 \%$ & \\
\hline
\end{tabular}

Source: Merchandise Trade Matrix: detailed products, exports in thousands of dollars, annual, 1995-2016, UNCTAD

of $15 \%$ ranking third, and crude materials consisted of $17 \%$ ranking second, but mineral fuels ranked first at 29\% increasing from 2\% in 1995 (refer to Table 5 and Figure 4).

Exports to the UAE showed that in 1995, manufactured goods comprised of $41 \%$ of total exports ranking first, followed by machinery and transport equipment with a share of $28 \%$ and ranked second. In 2015, miscellaneous manufactured goods consisted of 31\% ranking first, followed by manufactured goods at 20\%, followed by crude materials, inedible, except fuels at $15 \%$ (jumping from a meagre $7 \%$ in 1995), together with machinery and equipment at $15 \%$ as well ranking third jointly (refer to Table 6 and Figure 5).

Please see Appendix Table A1 for a detailed category description of the export product groupings. 


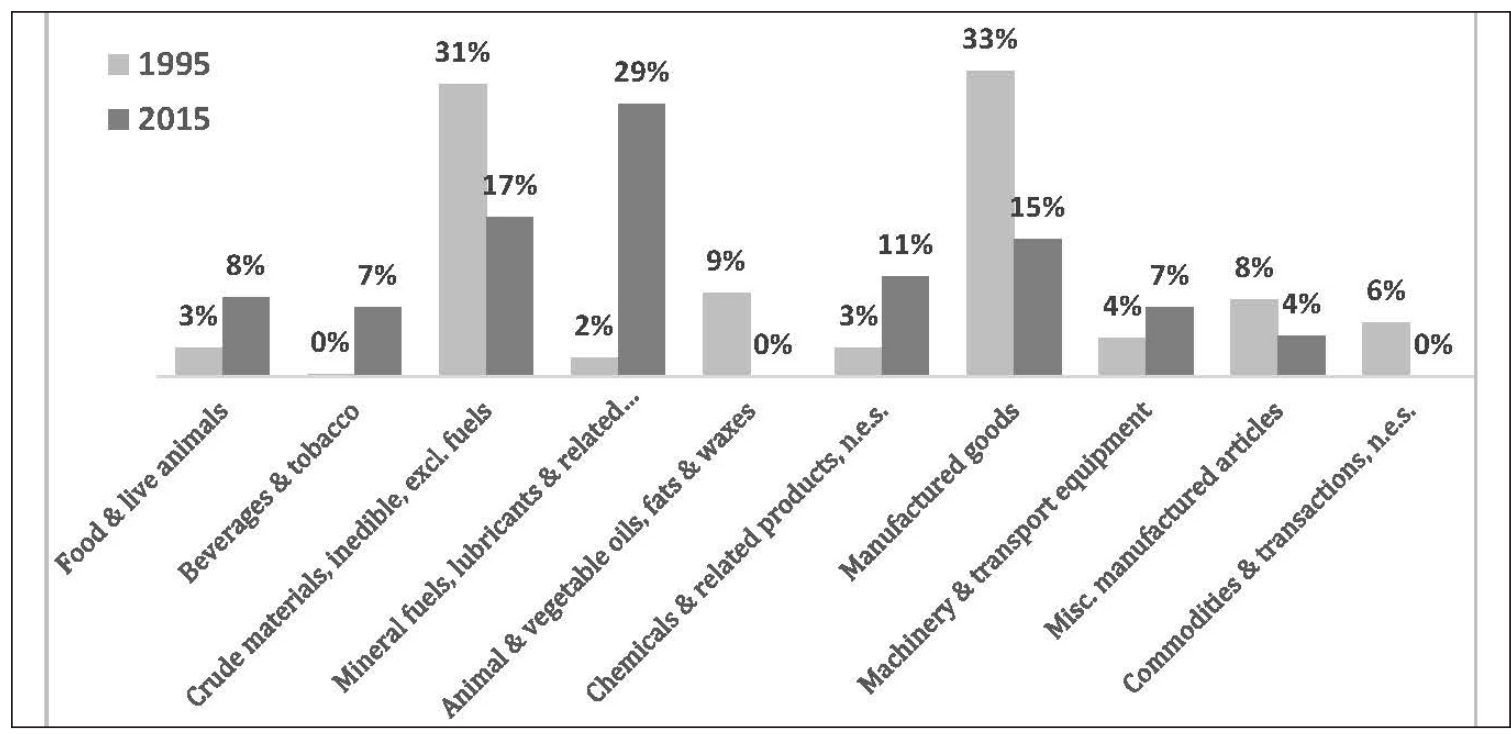

Figure 4 Primary Export Categories to Qatar, 1995 vs. 2015

Source: Merchandise Trade Matrix: detailed products, exports in thousands of dollars, annual, 1995-2016, UNCTAD

Table 6 Bahrain Exports to UAE by Composition, 1995 vs. 2015

\begin{tabular}{|c|c|c|c|c|}
\hline Product Category (incl. SITC code) & $\begin{array}{c}1995 \\
\text { (\% of Total) }\end{array}$ & rank & $\begin{array}{c}2015 \\
\text { (\% of Total) }\end{array}$ & rank \\
\hline [0] Food and live animals & $2 \%$ & & $5 \%$ & \\
\hline [1] Beverages and tobacco & $2 \%$ & & $0 \%$ & \\
\hline [2] Crude materials, inedible, except fuels & $7 \%$ & & $15 \%$ & 3 \\
\hline [3] Mineral fuels, lubricants and related materials & $0 \%$ & & $9 \%$ & \\
\hline [4] Animal and vegetable oils, fats and waxes & $10 \%$ & 3 & $0 \%$ & \\
\hline [5] Chemicals and related products, n.e.s. & $3 \%$ & & $4 \%$ & \\
\hline [6] Manufactured goods & $41 \%$ & 1 & $20 \%$ & 2 \\
\hline [7] Machinery and transport equipment & $28 \%$ & 2 & $15 \%$ & 3 \\
\hline [8] Miscellaneous manufactured articles & $7 \%$ & & $31 \%$ & 1 \\
\hline [9] Commodities and transactions, n.e.s. & $1 \%$ & & $1 \%$ & \\
\hline
\end{tabular}

Source: Merchandise Trade Matrix: detailed products, exports in thousands of dollars, annual, 1995-2016, UNCTAD

\section{Findings}

From Tables 2-6 and Figures 1-5, comparison of the man sectors in two separate years, namely 1995 and 2015, have been identified. The composition of export products during the years 19952015, and the movement of the categories between ranks, can be analysed through Figures 6-11. From Figure 6, six broad categories of export products $^{2}$ consist of the main categories of exports to Saudi Arabia during 1995-2015. Manufactured goods have declined in importance over

${ }^{2}$ Namely manufactured goods, machinery and transport equipment, crude materials, inedible, excluding fuels, chemicals and related products, food and live animals, miscellaneous manufactured articles. 


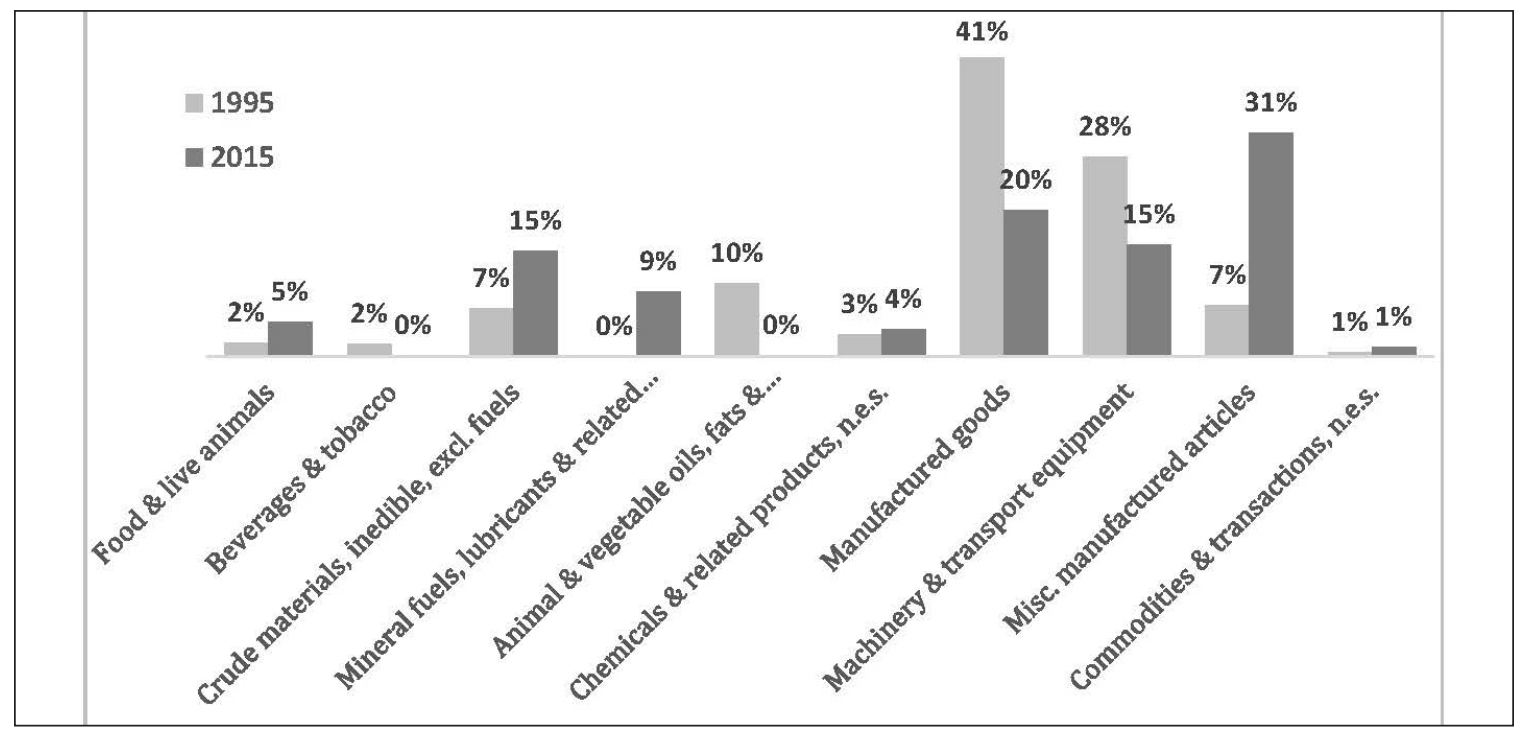

Figure 5 Primary Export Categories to UAE, 1995 vs. 2015

Source: Merchandise Trade Matrix: detailed products, exports in thousands of dollars, annual, 1995-2016, UNCTAD

the years, especially from 2008, giving way to transport and machinery equipment to take up a sizeable share, accompanied by miscellaneous manufactured articles, chemicals and related products, food and live animals, which do not show any significant trend.

Figure 7 shows five major product categories of export to Kuwait ${ }^{3}$, making up more than $90 \%$ of total exports in almost all years between 1995 and 2015. Manufactured goods have shown a steady decline since 2010, and the machinery and transport equipment category have depicted a steady share from 2004, with a marginally increasing trend in recent years. The other product categories, namely food and live animals, miscellaneous manufactured goods, and chemical related products, have shown no trend over the years.

Figure 8 shows the export categories to Oman, which have constituted the majority of export share, with less apparent trends. Only manufactured goods show a declining share in total exports, while other product categories show no trend over the period 1995-2015.

Figure 9 shows that no trend exists in exports of Bahrain to Qatar in the five major export categories, namely crude materials, inedible, excluding fuels, mineral fuels, lubricants and related materials, machinery and transport equipment, chemicals and related products, and manufactured goods.

Figure 10 shows five categories ${ }^{4}$ as dominating the share of total exports to the UAE, between 80-90\% during 1995 to 2015, in most years. The main trends in the figure show that manufactured goods have shown a decline, and the machinery and transport equipment category has remained steady with a slightly increasing trend. Other categories do not exhibit a trend.

\footnotetext{
${ }^{3}$ These include manufactured goods, food and live animals, machinery and transport equipment, miscellaneous manufactured products, and chemical and related products.

${ }^{4}$ Manufactured goods, machinery and transport equipment, miscellaneous manufactured articles, crude materials, inedible, excluding fuels, mineral fuels, lubricants and related products.
} 


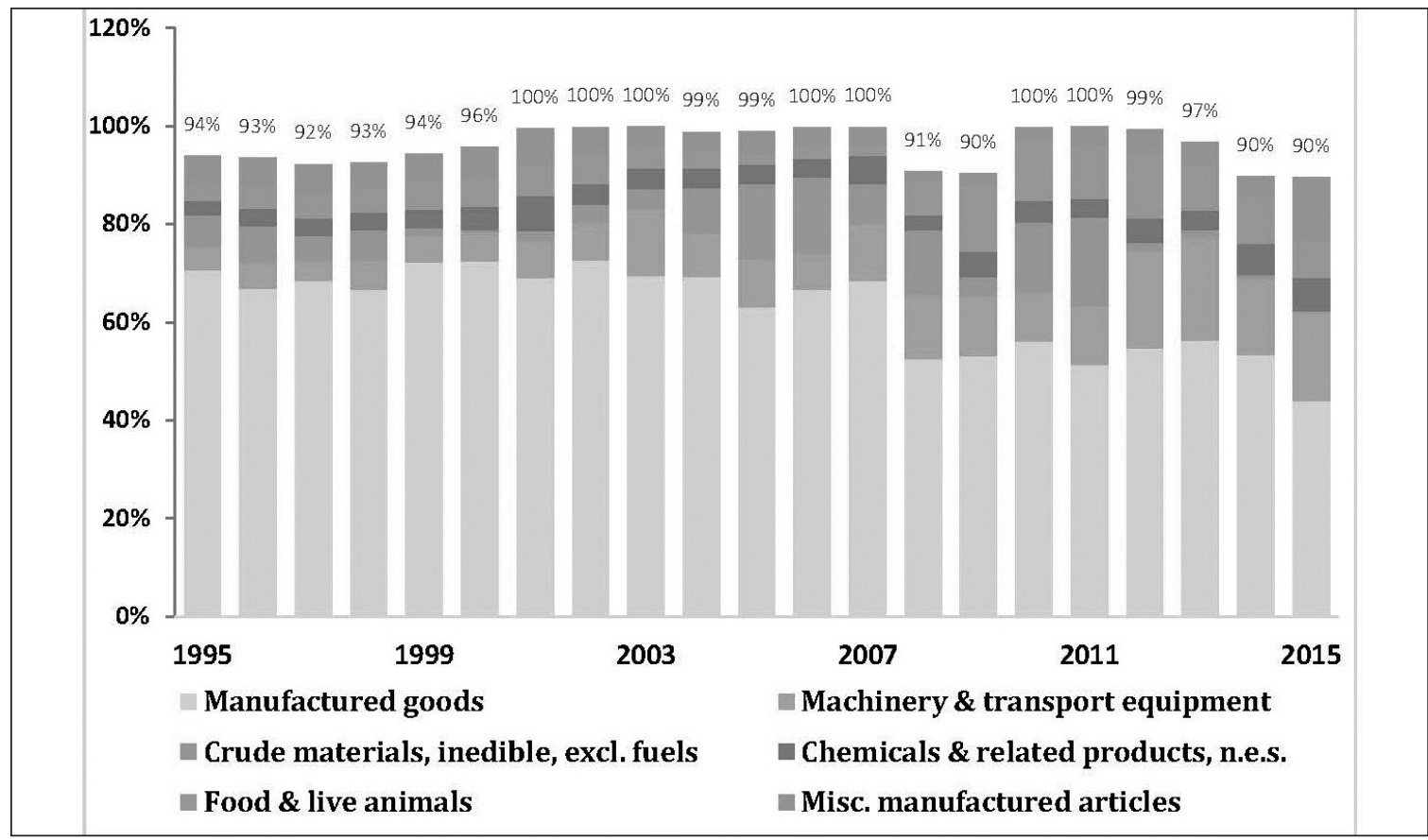

Figure 6 Primary Export Categories to Saudi Arabia, 1995-2015

Source: Merchandise Trade Matrix: detailed products, exports in thousands of dollars, annual, 1995-2016, UNCTAD

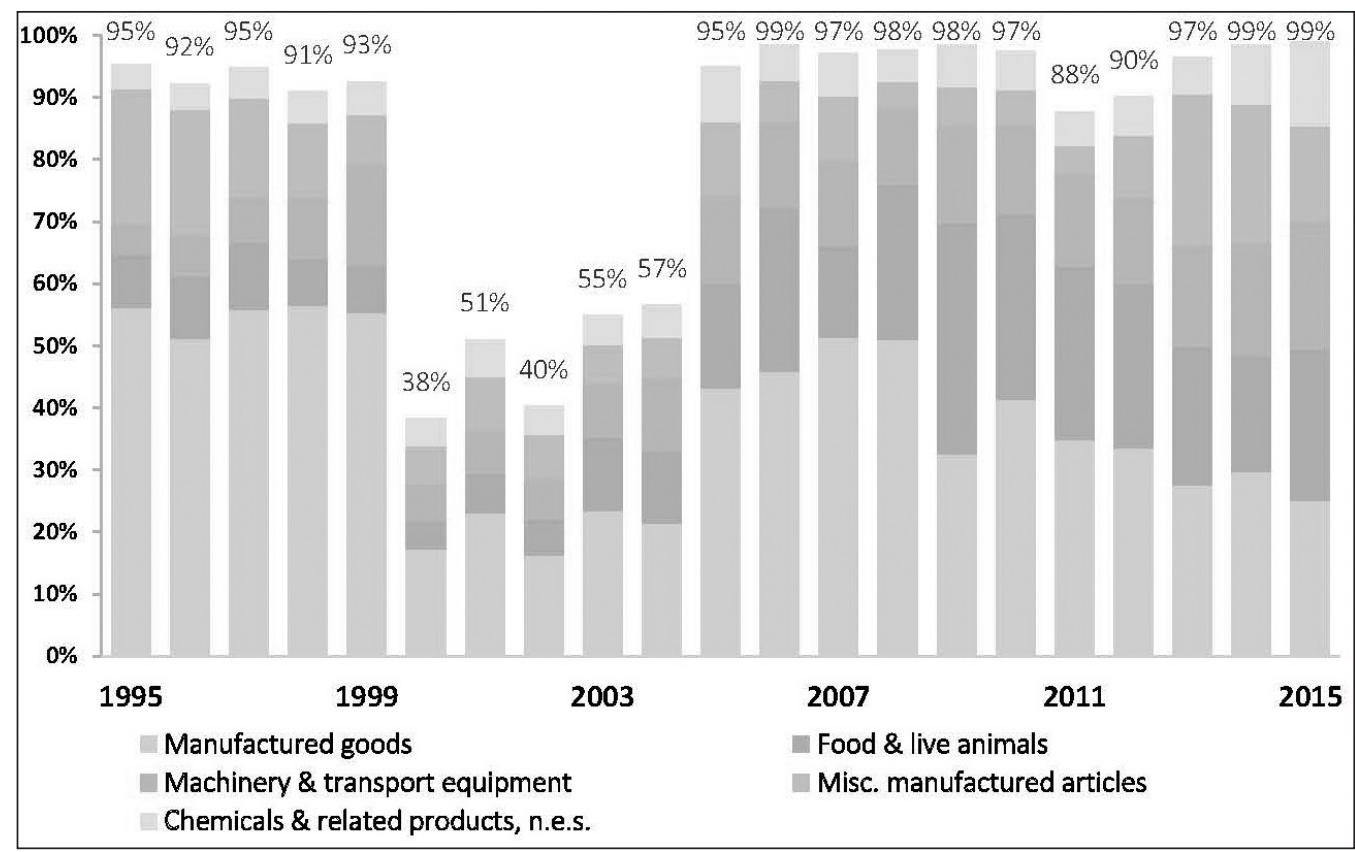

Figure 7 Primary Export Categories to Kuwait, 1995-2015

Source: Merchandise Trade Matrix: detailed products, exports in thousands of dollars, annual, 1995-2016, UNCTAD 


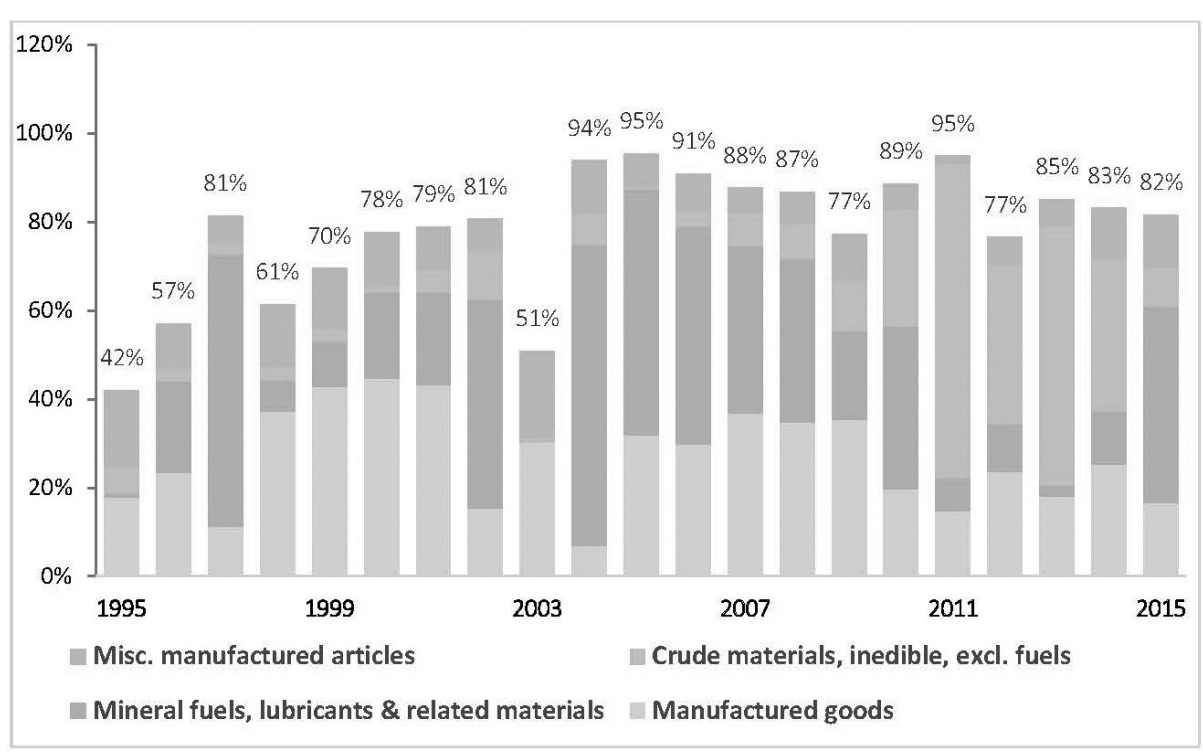

Figure 8 Primary Export Categories to Oman, 1995-2015

Source: Merchandise Trade Matrix: detailed products, exports in thousands of dollars, annual, 1995-2016, UNCTAD

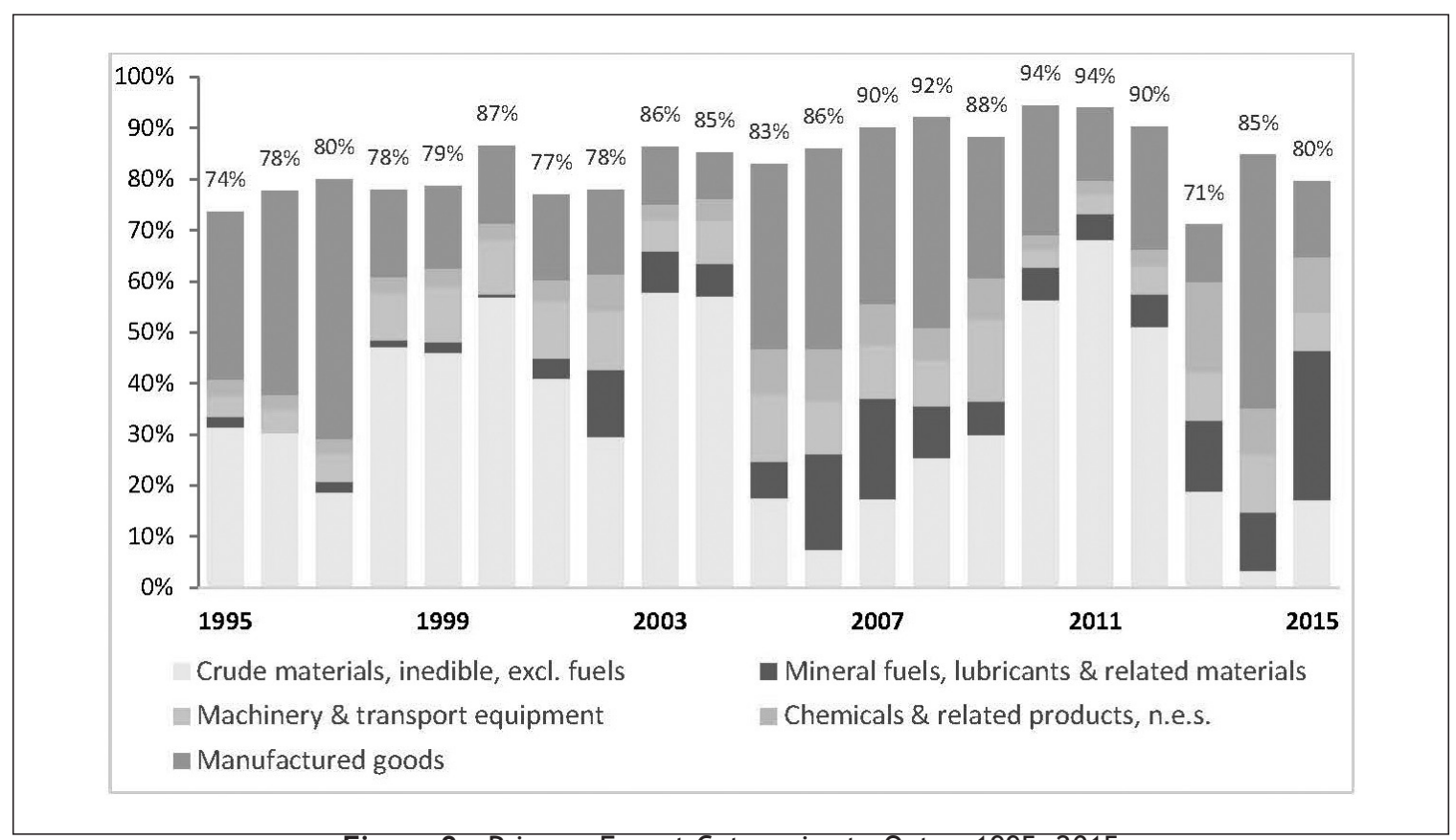

Figure 9 Primary Export Categories to Qatar, 1995-2015

Source: Merchandise Trade Matrix: detailed products, exports in thousands of dollars, annual, 1995-2016, UNCTAD

Figure 11 shows the composition of Bahrain's exports to each of the GCC countries as a percentage of total exports to the GCC. It shows that Saudi Arabia and the UAE are the most important trading partners for Bahrain's exports, comprising of $50-60 \%$ and $20-30 \%$ of total GCC exports during 1995 to 2015 respectively. 


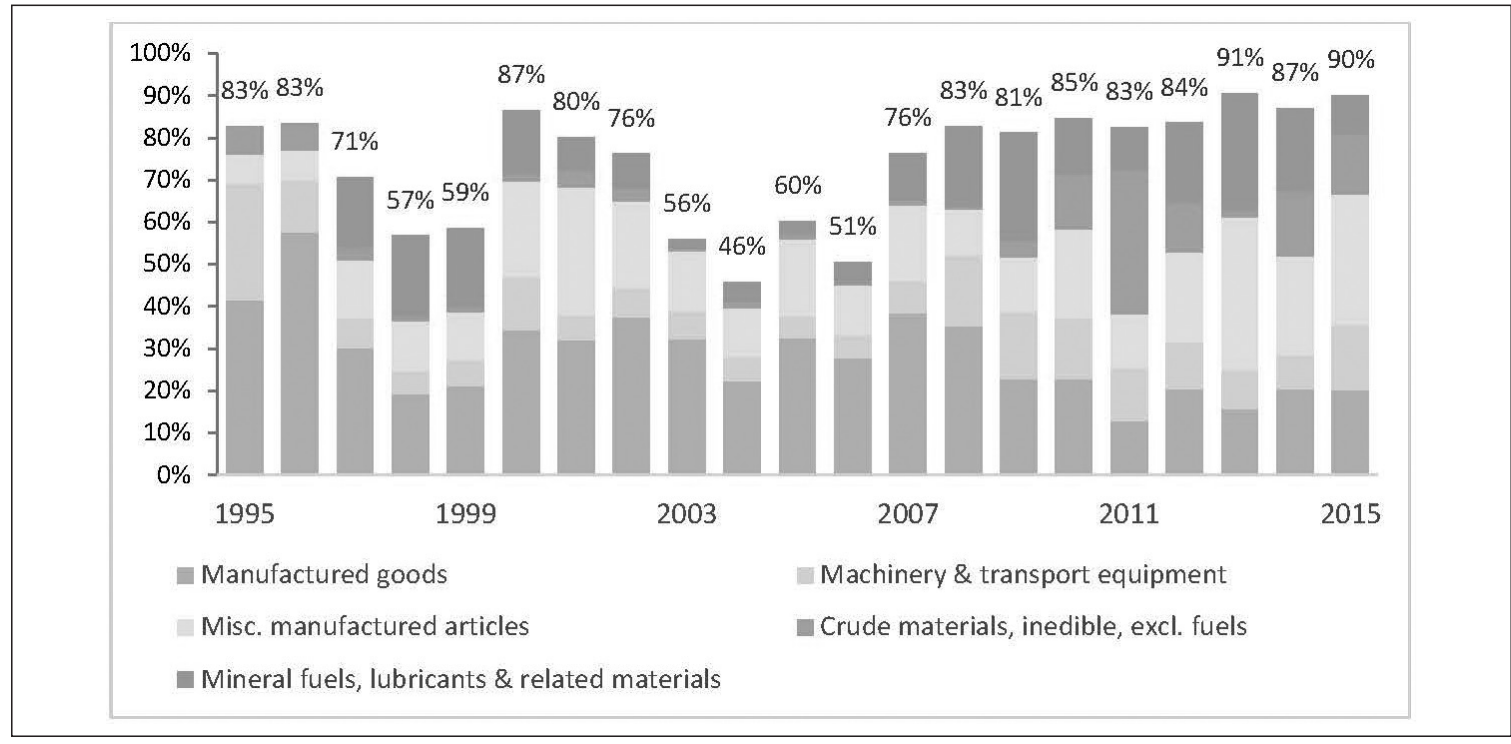

Figure 10 Primary Export Categories to UAE, 1995-2015

Source: Merchandise Trade Matrix: detailed products, exports in thousands of dollars, annual, 1995-2016, UNCTAD

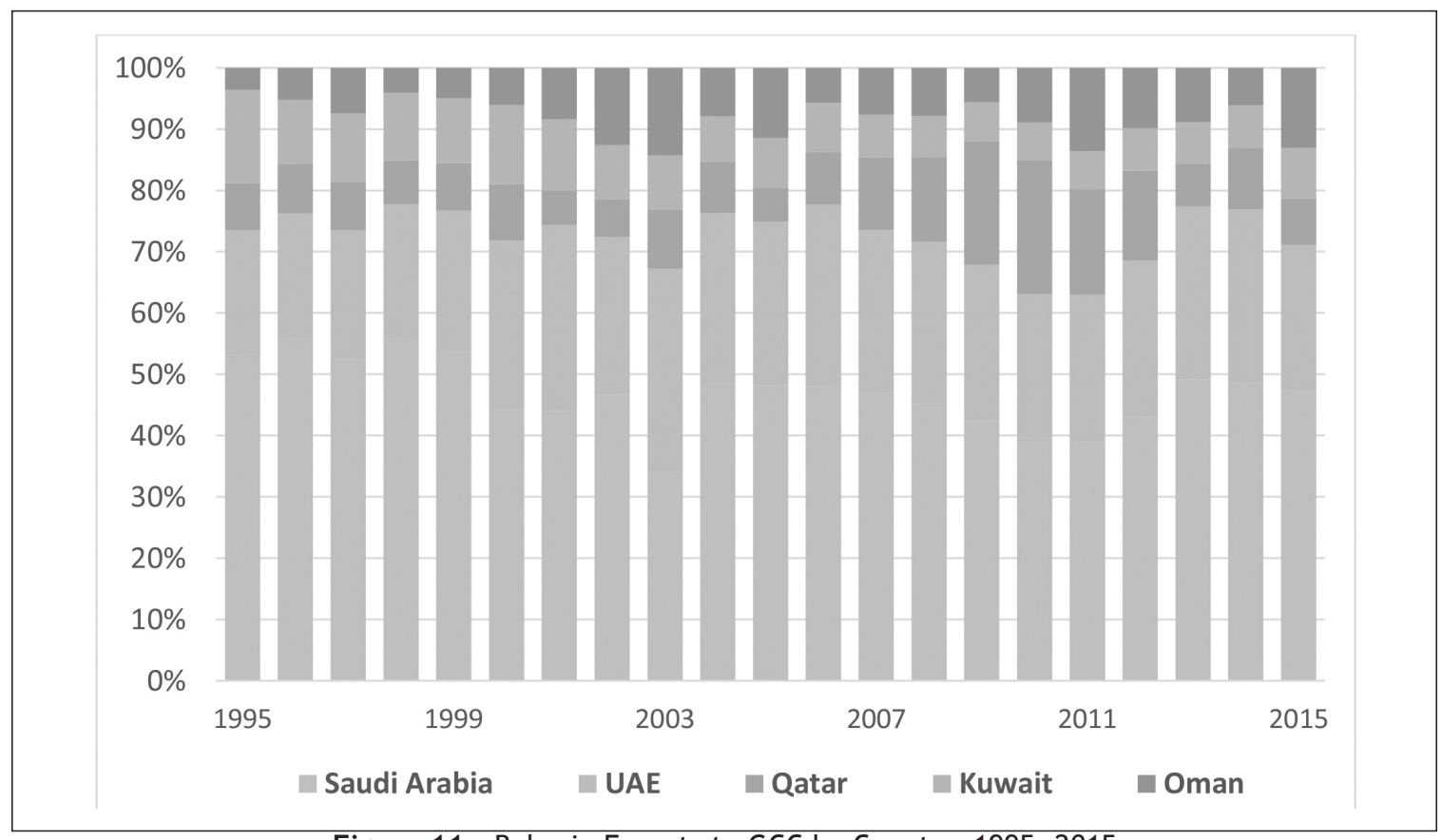

Figure 11 Bahrain Exports to GCC by Country, 1995-2015

Source: Merchandise Trade Matrix: detailed products, exports in thousands of dollars, annual, 1995-2016, UNCTAD

Figure 12 shows the change in the composition of Bahrain's exports during 1995-2015 to its GCC trading partners.

The product categories that have consistently made up at least $75 \%$ of the total Bahraini merchandise exports to the GCC comprised of manufactured goods, machinery and transport equipment, miscellaneous manufactured articles, crude materials, inedibles, excluding fuels, 


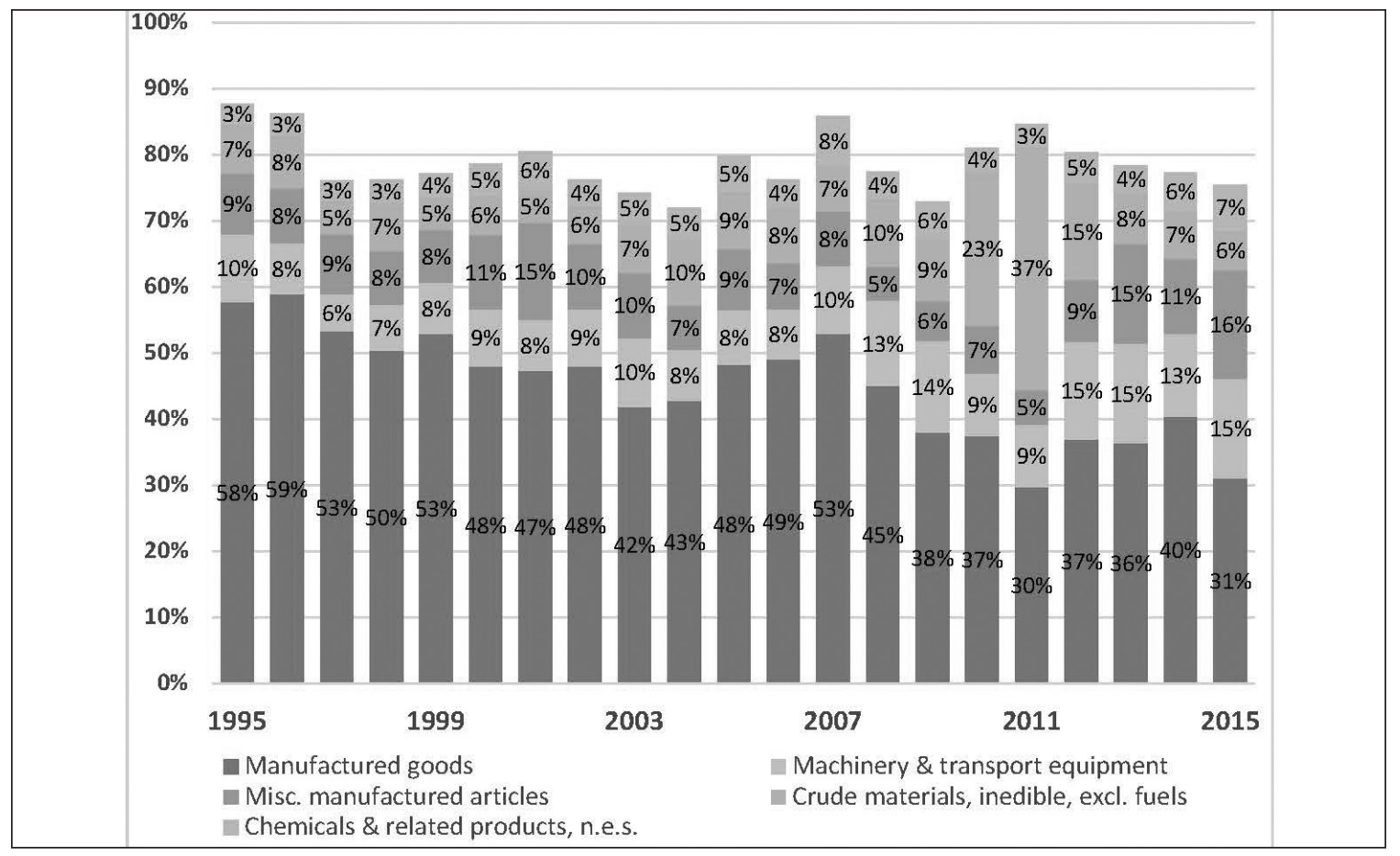

Figure 12 Bahrain Export Composition to GCC Countries, 1995-2015

Source: Merchandise Trade Matrix: detailed products, exports in thousands of dollars, annual, 1995-2016, UNCTAD

and chemicals and related products. Two of the most important trends that can be observed from Figure 12 are that manufactured items have reduced from $58 \%$ in total exports to the GCC to $31 \%$ over the years (with minor fluctuations in the interim period), while the machinery and transport equipment category has remained steady in its share of total exports since 2007, and increased marginally in the recent past.

Bahrain merchandise exports to the GCC countries show a declining trend between 1996 and 2015, with the biggest drop in 2015 at $33 \%$. This trend is restricted to merchandise exports only and does not reflect the total trade situation, which includes both goods and services. However, the long term trend shows a decline of Bahraini merchandise exports to the rest of the GCC. The reasons for such a slowdown are beyond the scope of this paper.

\section{CONCLUSIONS AND RECOMMENDATIONS}

One of the main pre-conditions for the existence and sustainability of a single currency monetary union is diversified trade between partners in a common currency zone. Past literature has concluded that due to oil dependency and lack of diversification, robust and diversified trade is not common in the GCC. Additionally, the volume of intra-GCC trade is small compared to a single currency zone, the EU for example. Ganguli (2016) argued that in the absence of convergence of the major macroeconomic indicators, GCC countries cannot create a single currency union in the absence of diversification and in the presence of low oil prices. Ganguli (2018, forthcoming) 


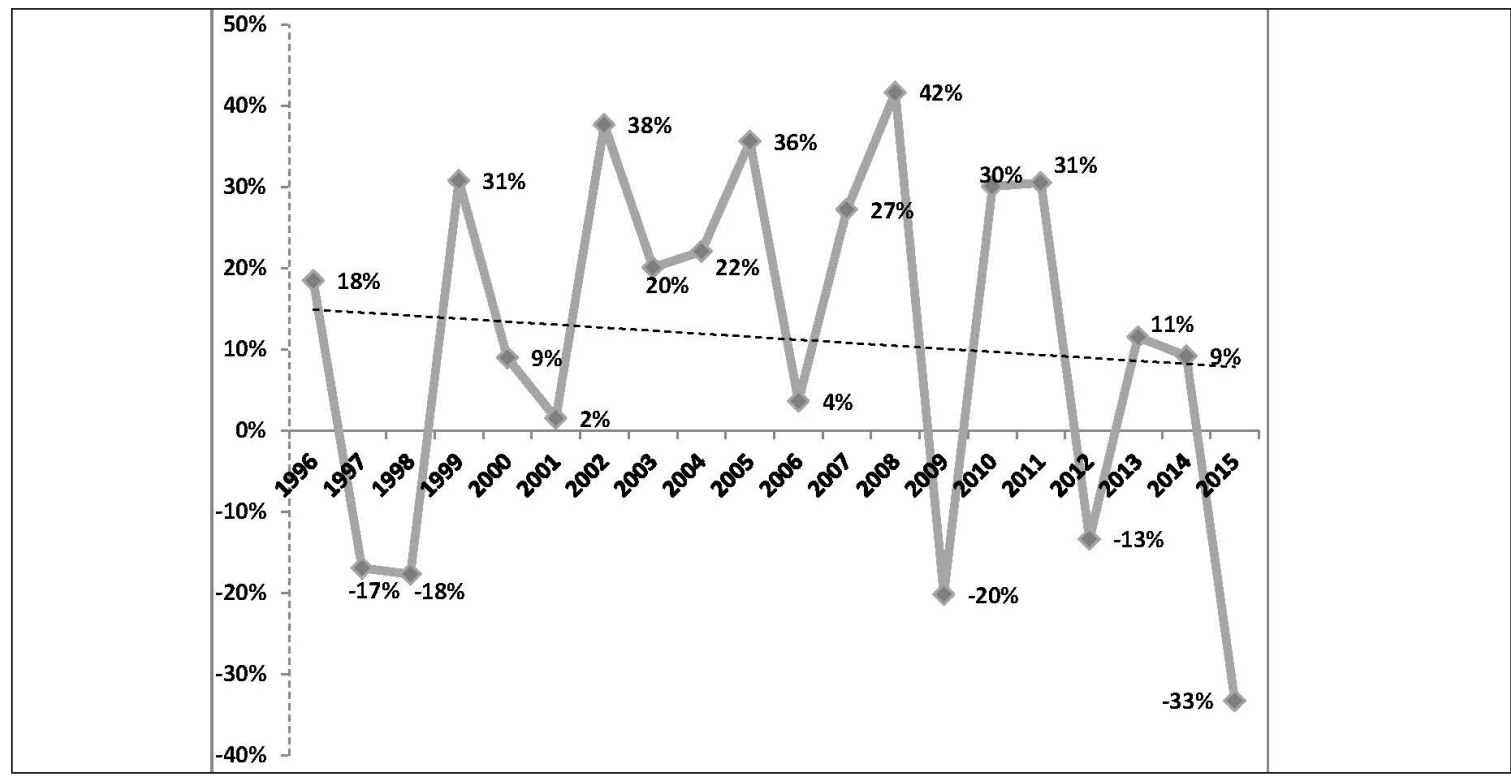

Figure 13 Bahrain Merchandise Export Growth to GCC Countries, 1996-2015

Source: Merchandise Trade Matrix: detailed products, exports in thousands of dollars, annual, 1995-2016, UNCTAD

further mentioned that, given the low volume of intra-GCC trade, Bahrain's merchandise export structure shows dissimilarity when compared with exports of other GCC states during 1995-2015.

The current paper analysed detailed Bahraini merchandise export trade data to the rest of the GCC during 1995-2015, to identify the diversity of exports in the face of diversification efforts of the Bahraini economy since the 1980s. The paper concludes that there was a distinct diversification of categories of export products to Saudi Arabia, which is also a major trading partner of Bahrain in the GCC, during 1995-2015. Manufactured goods exports from Bahrain have declined in the share of total exports, and machinery and transport equipment have increased, followed by other sectors.

Bahrain's exports to Kuwait have exhibited a steady decline in manufactured goods exports since 2010, followed by an increase in the share of machinery and transport equipment goods in recent years. Exports to Oman show a distinct decline of manufactured goods in the total share of exports, while there is no identifiable trend in exports of other product categories. Exports to Qatar show no trend in terms of the composition of product categories. The UAE is another major trading partner of Bahrain and exhibits a declining trend in share of manufactured goods within Bahrain's total exports. The machinery and transport equipment category has shown a slightly increasing trend during 1995-2015.

The paper concludes that there has been a shift in composition of major merchandise export items of Bahrain. Manufactured goods moved from a share of 58\% in 1995 in Bahrain's total GCC exports to $31 \%$ in 2015, while the machinery and transport equipment category has increased from $10 \%$ in 1995 to $15 \%$ in 2015 . This does not necessarily mean the importance of manufacturing items has declined in total exports. Manufactured goods ranks highly in the total exports to Saudi Arabia, Kuwait, and the UAE, although its share in total exports has declined. In most cases the machinery and transport equipment category has gained marginally in share and position. 
Other categories, namely miscellaneous manufactured articles, crude materials, inedible, excluding fuels, chemicals and related products, have either shown no major change in their share of total exports or have not maintained any significant share in the Bahrain's total export to the GCC. Manufacturing and industrial activity and logistics are two of the five main pillars of Bahrain's diversification, and one of the strong conclusions of the paper is that there is a distinct dominance of these two sectors in Bahrain's overall GCC exports, with a declining share of manufacturing and a steady or marginally increasing share of exports of machines and transport equipment showing the importance of logistics in the export products in recent years. There seems to be a positive relationship between the diversification efforts of the kingdom of Bahrain and the diversification trends of merchandise exports from Bahrain during the years 1995-2015. There has been an overall decline in exports from Bahrain to the GCC in 2015 (refer to Figure 13).

\section{Recommendations}

Future research should consider a quantitative analysis to establish the strength of the relationship and the causal nature of that relationship, if any, between the diversification of Bahrain's economy and the diversification of merchandise and services exports from Bahrain to the rest of the GCC. The results from such an exercise can guide policymakers in the GCC to create a successful and sustainable intra-GCC trade zone to further make the single currency and monetary union a reality and not a Utopian dream.

\section{Limitations}

The paper considers exports of products only based on UNCTADstats database, and excludes any relationship between services included in the diversification efforts of Bahrain and exports of the same. Future research should consider the exports of Bahraini services into the GCC and explore diversification trends, if any, commensurate with the diversification efforts of Bahrain's economy in the financial services, ICT and tourism sectors.

\section{APPENDIX}

Table A1 Breakdown of Section: 0 - Food and Live Animals

Breakdown of Section: 0 - Food and Live Animals

\begin{tabular}{cl}
\hline SITC Sub-code & \\
\hline 00 & Live animals other than animals of division 03 \\
01 & Meat and meat preparations \\
02 & Dairy products and birds' eggs \\
03 & Fish (not marine mammals), crustaceans, molluscs and aquatic invertebrates, and \\
04 & preparations thereof \\
05 & Cereals and cereal preparations \\
06 & Sugars, sugar preparations and honey \\
07 & Coffee, tea, cocoa, spices, and manufactures thereof \\
08 & Feeding stuff for animals (not including unmilled cereals) \\
09 & Miscellaneous edible products and preparations \\
\hline
\end{tabular}

Notes: Detailed structure and explanatory notes 


\section{(STANDARD INTERNATIONAL TRADE CLASSIFICATION, REVISION 3)}

- 0 - Food and live animals

○ 00 - Live animals other than animals of division 03

○ 01 - Meat and meat preparations

○ 02 - Dairy products and birds' eggs

○ 03 - Fish (not marine mammals), crustaceans, molluscs and aquatic invertebrates, and preparations thereof

○ 04 - Cereals and cereal preparations

○ 05 - Vegetables and fruit

○ 06 - Sugars, sugar preparations and honey

○ 07 - Coffee, tea, cocoa, spices, and manufactures thereof

○ 08 - Feeding stuff for animals (not including unmilled cereals)

○ 09 - Miscellaneous edible products and preparations

- 1 - Beverages and tobacco

o 11 - Beverages

O 12 - Tobacco and tobacco manufactures

- 2 - Crude materials, inedible, except fuels

o 21 - Hides, skins and furskins, raw

O 22 - Oil-seeds and oleaginous fruits

○ 23 - Crude rubber (including synthetic and reclaimed)

O 24 - Cork and wood

O 25 - Pulp and waste paper

o 26 - Textile fibres (other than wool tops and other combed wool) and their wastes (not manufactured into yarn or fabric)

O 27 - Crude fertilizers, other than those of division 56, and crude minerals (excluding coal, petroleum and precious stones)

O 28 - Metalliferous ores and metal scrap

o 29 - Crude animal and vegetable materials, n.e.s.

- 3 - Mineral fuels, lubricants and related materials

○ 32 - Coal, coke and briquettes

○ 33 - Petroleum, petroleum products and related materials

○ 34 - Gas, natural and manufactured

○ 35 - Electric current

- 4 - Animal and vegetable oils, fats and waxes

○ 41 - Animal oils and fats

○ 42 - Fixed vegetable fats and oils, crude, refined or fractionated

○ 43 - Animal or vegetable fats and oils, processed; waxes of animal or vegetable origin; inedible mixtures or preparations of animal or vegetable fats or oils, n.e.s.

- 5 - Chemicals and related products, n.e.s.

- 51 - Organic chemicals

○ 52 - Inorganic chemicals 
O 53 - Dyeing, tanning and colouring materials

○ 54 - Medicinal and pharmaceutical products

○ 55 - Essential oils and resinoids and perfume materials; toilet, polishing and cleansing preparations

O 56 - Fertilizers (other than those of group 272)

○ 57 - Plastics in primary forms

○ 58 - Plastics in non-primary forms

○ 59 - Chemical materials and products, n.e.s.

- 6 - Manufactured goods classified chiefly by material

○ 61 - Leather, leather manufactures, n.e.s., and dressed furskins

○ 62 - Rubber manufactures, n.e.s.

○ 63 - Cork and wood manufactures (excluding furniture)

○ 64 - Paper, paperboard and articles of paper pulp, of paper or of paperboard

○ 65 - Textile yarn, fabrics, made-up articles, n.e.s., and related products

O 66 - Non-metallic mineral manufactures, n.e.s.

○ 67 - Iron and steel

○ 68 - Non-ferrous metals

O 69 - Manufactures of metals, n.e.s.

- 7 - Machinery and transport equipment

○ 71 - Power-generating machinery and equipment

○ 72 - Machinery specialized for particular industries

○ 73 - Metalworking machinery

○ 74 - General industrial machinery and equipment, n.e.s., and machine parts, n.e.s.

○ 75 - Office machines and automatic data-processing machines

○ 76 - Telecommunications and sound-recording and reproducing apparatus and equipment

○ 77 - Electrical machinery, apparatus and appliances, n.e.s., and electrical parts thereof (including non-electrical counterparts, n.e.s., of electrical household-type equipment)

O 78 - Road vehicles (including air-cushion vehicles)

○ 79 - Other transport equipment

- 8 - Miscellaneous manufactured articles

○ 81 - Prefabricated buildings; sanitary, plumbing, heating and lighting fixtures and fittings, n.e.s.

○ 82 - Furniture, and parts thereof; bedding, mattresses, mattress supports, cushions and similar stuffed furnishings

○ 83 - Travel goods, handbags and similar containers

○ 84 - Articles of apparel and clothing accessories

○ 85 - Footwear

○ 87 - Professional, scientific and controlling instruments and apparatus, n.e.s.

○ 88 - Photographic apparatus, equipment and supplies and optical goods, n.e.s.; watches and clocks

○ 89 - Miscellaneous manufactured articles, n.e.s. 


\section{- 9 - Commodities and transactions not classified elsewhere in the SITC}

○ 91 - Postal packages not classified according to kind

○ 93 - Special transactions and commodities not classified according to kind

○ 96 - Coin (other than gold coin), not being legal tender

○ 97 - Gold, non-monetary (excluding gold ores and concentrates)

- I - Gold, monetary

- II - Gold coin and current coin

Source: https: / / unstats.un.org/unsd/cr/registry/regcst. asp? $\mathrm{Cl}=14$

\section{REFERENCES}

Abdmoulah, W. (2011), Evidence from Zero Inflated Negative Binomial Model, Journal of Economic Cooperation and Development, Vol. 32, No. 2, pp.39-66.

Al Said, A. (2007), Intra-Regional Trade of Regional Trading Blocs: the Case of the Gulf Cooperation Council, unpublished PhD thesis, UWA Business School, University of Western Australia.

Alawadhi, A.S. (2014), Essays on Trade Integration Among GCC Countries, Unpublished PhD thesis, University of Southampton, UK.

Bahrain Economic Development Board (2017), Bahrain Economic Quarterly, June 2017, Kingdom of Bahrain.

Boughanmi, H. (2008), The Trade Potential of the Arab Gulf Cooperation Countries (GCC): A Gravity Model Approach, Journal of Economic Integration, Vol. 23, No. 1, pp.42-56

Ganguli, S. (2016), An economic analysis of sustainability of a potential GCC economic and monetary union during 2005-2014, World Journal of Entrepreneurship Management and Sustainable Development, Vol. 12, No. 3, pp. 194-206.

Ganguli, S. (2018), Economic Diversification and Intra-GCC Merchandise trade: An Empirical Analysis during 1995-2015, World Journal of Entrepreneurship Management and Sustainable Development, Vol. 14, No. 1 (forthcoming).

Ganguli, S. and Matar, R.H. (2016), A sample survey analysis of the effectiveness of training and development initiatives in Bahrain's financial sector on employability of Bahraini nationals in 2015, World Journal of Entrepreneurship Management and Sustainable Development, Vol. 12, No. 4, pp.359-83.

Hossain, A. and Naser, K.(2008), Trade and regional integration: analysis of the effectiveness in the GCC, International Journal of Islamic and Middle Eastern Finance and Management, Vol. 1, No. 2, pp.95-112.

IMF (2017), Bahrain Assessment of the IMF 2017, https://www.imf.org/en/News/Articles/2017/08/21/ pr17331-bahrain-executive-board-concludes-2017-article-iv-consultation

IMF Staff (2016), Economic Diversification in Oil-Exporting Arab Countries, Annual Meeting of Arab Ministers of Finance, April 2016, Manama, Bahrain.

Nechi, S. (2010), Assessing Economic and Financial Cooperation and Integration Among the GCC Countries, Journal of Business and Policy Research, Vol. 5, No. 1, pp.158-78.

Ravi, N. (2013), Intra Regional Trade Among Gulf Cooperation Council, The Macrotheme, Review, Vol. 2, No. 3, pp.108-114.

Sahib, A.S.A. and Kari, F. (2012), Analysis of Intensity of Intra-Regional Trade in GCC Countries, 1998-2008, International Journal of Trade, Economics and Finance, Vol. 3, No. 3, pp.223-26.

Stevenson, B. (2017), The Best and Worst Countries to Live and Work In, According to Expats, Bloomberg.

Townsend, S. (2017), Where is Bahrain headed?, http://www.arabianbusiness.com/where-is-bahrain-headed--667365.html. 


\section{BIOGRAPHY}

Dr Subhadra Ganguli has been an Associate professor in the Department of Accounting and Economics in the College of Business and Finance at Ahlia University in the Kingdom of Bahrain since 2014. She has a PhD in Economics from the University of California at Riverside, and has completed the Leadership Development Program at Darden Business School at the University of Virginia. She specialises in international economics, environmental economics and the economics of the GCC. She has worked across India, USA, Europe and the GCC in areas of consulting, research and quality assurance, in addition to teaching and training. She is a visiting faculty and an undergraduate dissertation supervisor at Aalto University School of Business in Mikkeli, Finland in the International Business Program. 